\title{
Xiphactinus audax Leidy 1870 from the Puskwaskau Formation (Santonian to Campanian) of north- western Alberta, Canada and the distribution of Xiphactinus in North America
}

\section{Matthew J. Vavrek ${ }^{1}$, Alison M. Murray ${ }^{2}$ and Phil R. Bell ${ }^{3}$}

${ }^{1}$ Royal Ontario Museum, Department of Natural History, 100 Queen's Park, Toronto, ON M5S 2C6, Canada, matthew@matthewvavrek.com

${ }^{2}$ Department of Biological Sciences, University of Alberta, Edmonton, AB T6G 2E9, Canada, ammurray@ualberta.ca ${ }^{3}$ Department of Environmental and Rural Science, University of New England, Armidale, NSW 2351, Australia, pbell@une.edu.au

\begin{abstract}
Xiphactinus is the largest teleost fish known from the Late Cretaceous of North America, and has been found across much of the Western Interior Basin. Despite extensive Late Cretaceous marine deposits occurring in Alberta, there has previously been only two possible records of Xiphactinus from the province, neither of which has been diagnosable to the species level. We describe here a portion of the lower jaws, including teeth, of Xiphactinus audax from northeast of Grande Prairie, Alberta. The fossil has large, thecodont teeth that are circular in cross section and lack any carinae, and are highly variable in their overall size. This fossil is the first diagnostic material of $X$. audax from Alberta, and extends the range of the species by over a thousand kilometres. During the Late Cretaceous, the area the fossil was found in was near the Arctic Circle, and represents an important datapoint within the poorly known, northern portion of the Western Interior Basin.
\end{abstract}

Key Words: Ichthyodectiformes; Late Cretaceous; marine; Teleostei; Western Interior Basin

\section{INTRODUCTION}

The ichthyodectid Xiphactinus is the largest teleost fish known from the Late Cretaceous of North America (Bardack 1965; Schwimmer et al. 1997; Shimada et al. 2006). Specimens of Xiphactinus have been found from Cenomanian (Cumbaa et al. 2006) through Campanian (DeMar and Breithaupt 2006) deposits throughout much of the southern Western Interior Basin, from central Saskatchewan (Cumbaa and Tokaryk 1999; Cumbaa et al. 2006) south to Texas (Bardack 1965), as well as Campanian to Maastrichtian beds along the Atlantic coast in New Jersey (Grandstaff et al. 1992), North Carolina, Georgia and Alabama (Schwimmer et al. 1997). Although known from a variety of formations, the most spectacular specimens of Xiphactinus come from the Niobrara Formation of Kansas, where well-preserved, virtually complete skeletons were being excavated as early as the 1870 s (Cope 1872; Bardack 1965). Some of these nearly complete specimens are close to $5 \mathrm{~m}$ in total length, although isolated elements

Published 4 February, $2016 \odot 2016$ by the authors submitted August 23, 2015; revisions received January 28, 2016; accepted January 29, 2016. Handling editor: Robert Holmes. from even larger individuals are also known (Bardack 1965; Shimada and Everhart 2004).

Despite extensive marine deposits in Alberta, to date only two other questionable records of Xiphactinus have been reported from the province. The first record is from "east of Lesser Slave Lake" noted by Bardack (1965). However, he listed no referred material and gave no description of any specimen, with the record consisting only of a personal communication from Wann Langston. A search of likely museum collections where any such fossils would have been accessioned has yielded nothing. The general lack of appropriate-aged fossil bearing deposits from that area, as well as the lack of referable or figured specimens, makes this record dubious. A second Albertan record consists of two isolated scales from the Kaskapau Formation near Watino, Alberta (Wilson and Chalifa 1989), although those authors note that the scales do not conform in every aspect with those of Xiphactinus and so referred the specimens to "cf. Xiphactinus".

The specimen we describe here, TMP 1973.011.3081, was first mentioned in an unpublished $\mathrm{PhD}$ thesis by Christopher Collom (2001), and later mentioned again by Bell et al. (2014). However, the specimen itself was never 
described and was only assigned to the genus Xiphactinus. Further study of the specimen has revealed a number of characteristics that allow the assignment of the specimen more precisely to Xiphactinus audax, expanding the range of this species considerably. The specimen itself is notable for its relatively northern location within the Western Interior Seaway, and also confirms and fully documents the presence of Xiphactinus in Alberta.

Institutional Abbreviations: CMN, Canadian Museum of Nature, Ottawa, Ontario, Canada; TMP, Royal Tyrrell Museum of Palaeontology, Drumheller, Alberta, Canada; UALVP, University of Alberta Laboratory for Vertebrate Palaeontology, Edmonton, Alberta, Canada.

\section{GEOLOGICAL SETTING}

The Puskwaskau Formation is a marine, mudstone-dominated wedge up to $350 \mathrm{~m}$ in thickness, that was deposited in relatively shallow waters of the Western Interior Seaway (Hu and Plint 2009). The Puskwaskau was deposited during the Niobrara Cycle (Kauffman 1977), and is Santonian to early Campanian in age (Hu and Plint 2009; Fig. 1). The Puskwaskau is divided into five members, which are, in ascending order, Dowling, Thistle, Hanson, Chungo and Nomad (Stott 1963, 1967; Hu and Plint 2009). Collom (2001) suggested that the Santonian/Campanian boundary is within the upper part of the Hanson Member, placing the Chungo and Nomad members within the lower Campanian.
Although the exact stratigraphic position of the fossil is unknown, the matrix still attached to the fossil is similar in nature to a number of other marine vertebrate specimens found in the area, particularly those discussed by Bell et al. (2014). The majority of the specimens discussed in that paper were inferred to have come from the upper portions of the Puskwaskau Formation, likely the Chungo or Nomad members (Bell et al. 2014). This is further corroborated by the location where TMP 1973.011.3081 was found, on a relatively small, shallow creek that drains a limited area. Geologic maps of the region indicate that the creek drains an area that is mainly part of the upper portions of the Puskwaskau Formation, concordant with the idea that the fossil comes from one of the upper members of the formation. Assuming TMP 1973.011.3081 is from one of these upper members, it would be early Campanian in age.

\section{SYSTEMATIC PALAEONTOLOGY}

\section{Order ICHTHYODECTIFORMES Bardack and} Sprinkle, 1969

Family ICHTHYODECTIDAE Patterson and Rosen 1977 Genus Xiphactinus Leidy 1870

Xiphactinus audax Leidy 1870

Figure 2

Referred Material: TMP 1973.011.3081, the anterior portion of articulated left and right dentaries.
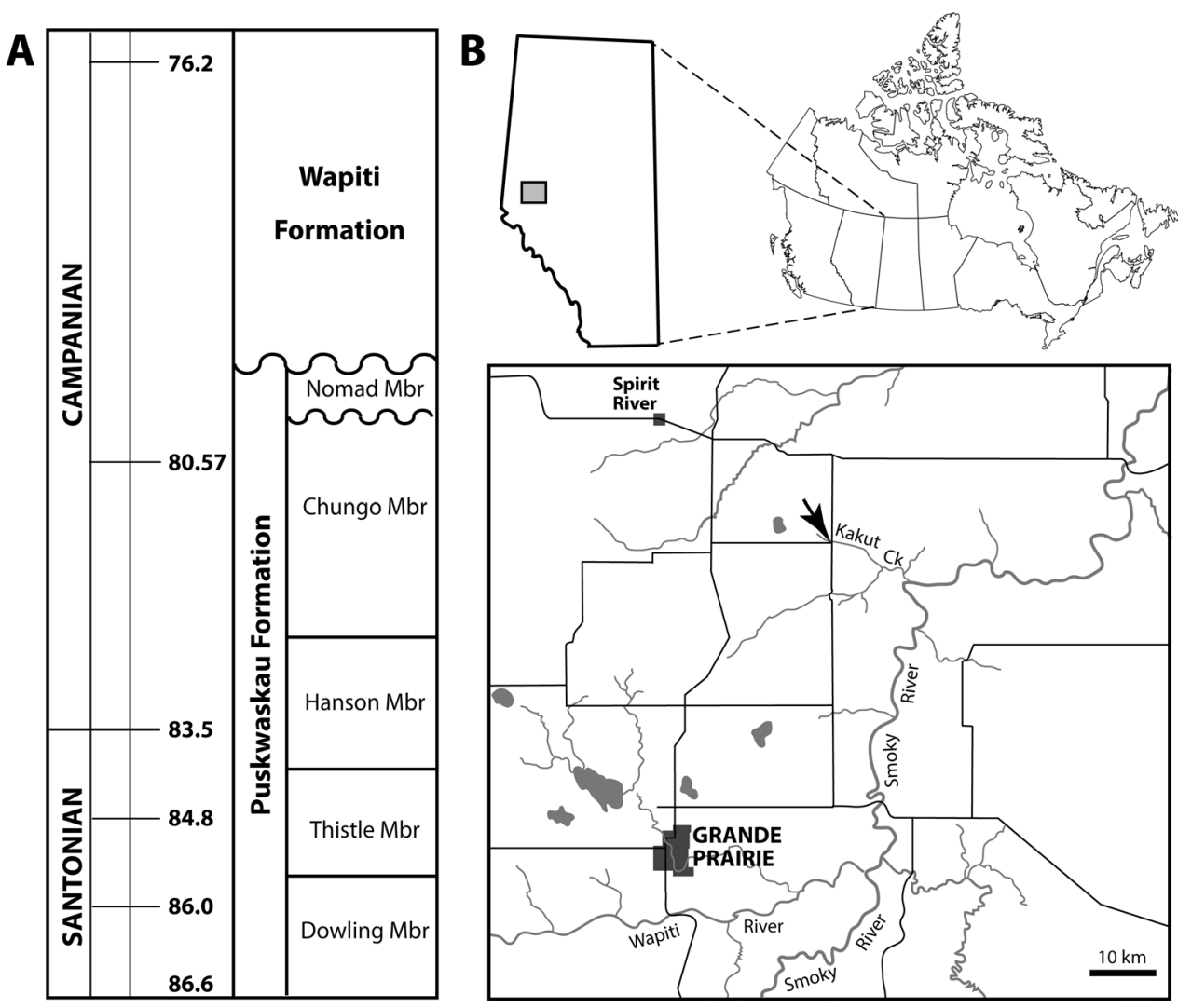

Figure 1. A) Summary stratigraphic chart for the Santonian to early Campanian of northwestern Alberta. B) Maps showing, counter-clockwise from top right: location of Alberta within Canada; location of regional map of Grande Prairie area within Alberta; location of fossil site along Kakut Creek, northeast of Grande Prairie. Location of TMP 1973.011.3081 is marked with an arrow. 

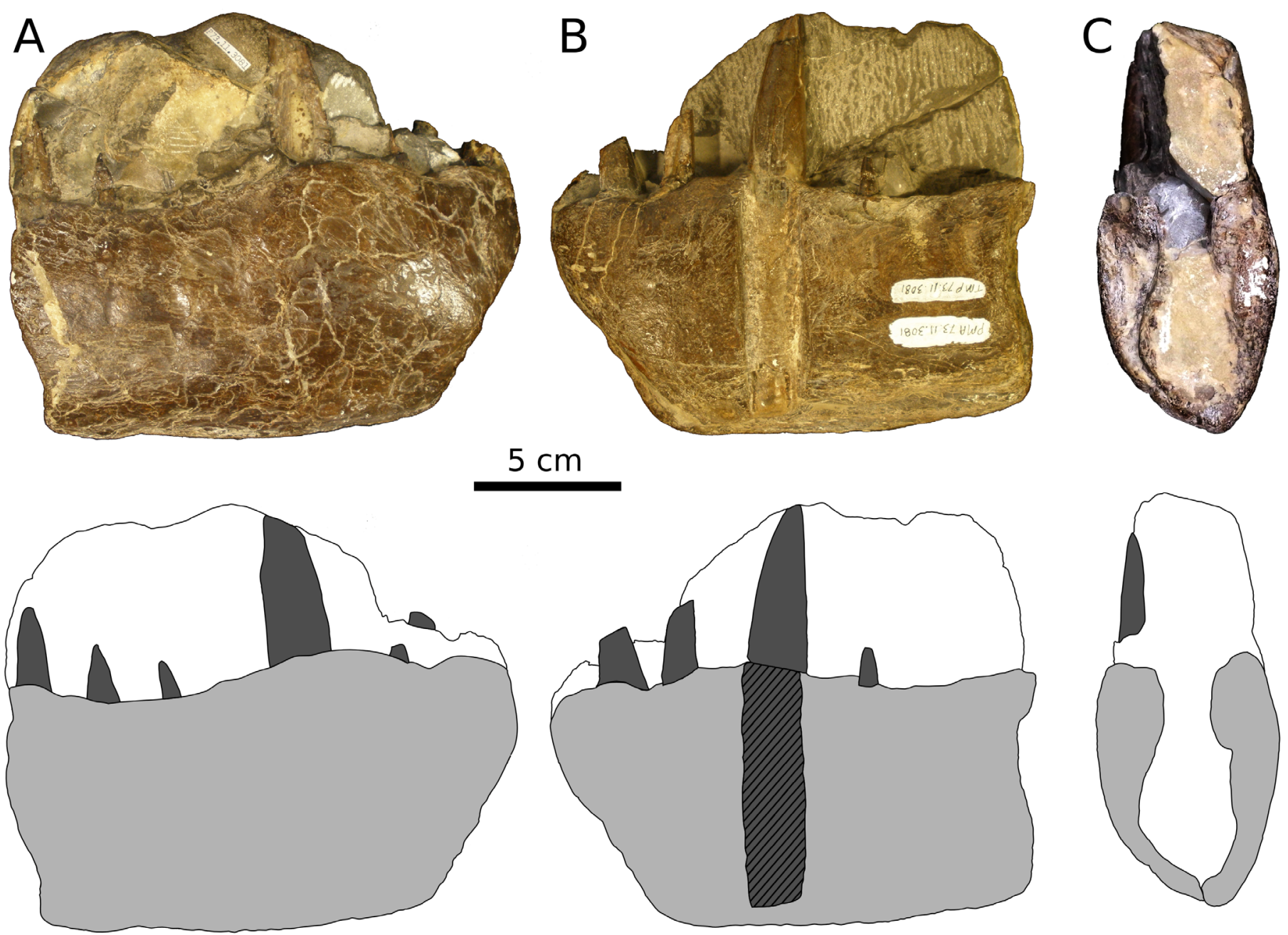

Figure 2. TMP 1973.011.3081, partial jaws of Xiphactinus audax Leidy 1870. A) Right lateral view. B) Left lateral view. C) Posterior view. For all line drawings matrix is shaded white, bone is shaded light grey, teeth are shaded dark grey, and cross-hatching indicates areas of exposed tooth root.

Locality and Horizon: The fossil was likely collected sometime in the 1950s or 1960s, based on the personal collection records of George Robinson, the original collector. The notes associated with the fossil in the TMP collections state that the specimen was "from the Bad Heart River near bridge." However, in Robinson's original collections ledger, he noted that he found the fossil along "Kakut $C^{k}$ near bridge on Wanham Rd" and that it came from the "Bad Heart Sst." Another note he made, beside the entry for several invertebrate specimens collected from the same location, states that the bridge had been replaced by a culvert. His description, and comparison with historical maps of the area and modern maps, shows that the fossil came from exposures near Kakut Creek where the present day Secondary Highway 733 crosses it, at approximately $55.61^{\circ} \mathrm{N} 118.39^{\circ} \mathrm{W}$. The exact horizon the fossil came from is unknown, and it was likely found ex situ, as the unprepared portions of matrix still attached appear to have been water worn, likely from sitting in the creek itself for some time.
Description: TMP 1973.011.3081 preserves approximately the anterior one-third of the left and right dentaries, and measures $16 \mathrm{~cm}$ long. The dentary symphysis forms a sigmoidal curve in lateral view with a tooth positioned on each side right beside the symphysis. The pores for the mandibular canal are not clearly visible as this area of the jaw is somewhat distorted and very worn. The symphysis measures $9.2 \mathrm{~cm}$ in a straight line from the lower edge to the upper, which is close to the average length for $X$. audax $[8.7 \mathrm{~cm}$ with a range of 6.0-13.85 based on measurements of 81 specimens (Bardack 1965)]. The dorsal surfaces of the dentaries undulate, being deepest under the largest tooth.

There are six right and six left tooth positions preserved, some of which contain almost complete teeth while others are represented only by the tooth base. The two anterior-most teeth on either side of the symphysis are fairly large, and would have reached an estimated $3 \mathrm{~cm}$ above the dentary bone. The third tooth on each side are the largest of the preserved teeth. The third tooth on the left side is almost 
complete, missing only a small portion at the labial side of the tip, and reaches $5.5 \mathrm{~cm}$ above the dentary bone. The dentary in this area had been prepared away so that the tooth root is visible (Fig. 2B). The tooth is clearly thecodont as the root reaches all the way to the ventral margin of the jaw, making the complete tooth just short of $13 \mathrm{~cm}$ long. The fourth tooth, visible on both sides, is the smallest present, and quite slender. The almost complete left fourth tooth is $1.2 \mathrm{~cm}$ high, and would have been only slightly taller when complete. Only the bases of the fifth and sixth teeth on the left dentary are preserved. On the right dentary, the tip of the fifth tooth is present, and this tooth is $1.8 \mathrm{~cm}$ above the margin of the bone. The sixth tooth is almost as large as the anterior teeth, at about $2.8 \mathrm{~cm}$ tall.

The root of the largest tooth on the left side, where the jaw bone has been removed, can be seen clearly, and it is round in cross section. The tooth bases of the fifth and sixth positions on the left dentary are also round in cross section. None of the preserved teeth possess carinae. Because the jaw is broken at the posterior end, the cross-sectional shape of the two dentaries can be seen. The alveolar surface is much wider than the ventral part of the dentary. The cross section is comma shaped, with the ventral tail of the comma curving medially (Fig. 2C).

Remarks: Ichthyodectes and Gillicus, the two other large Cretaceous ichthyodectid fishes known from North America, both have teeth that are much smaller and of more uniform size than those of Xiphactinus (e.g., Bardack, 1965). Species of Xiphactinus have much larger teeth and display heterodonty in their size. Therefore, this specimen clearly belongs to Xiphactinus. Additionally, Schwimmer et al. (1997) noted the characteristic thecodont dentition of Xiphactinus - this is well exemplified in the Alberta specimen by the tooth exposed by preparation so that the whole root, reaching to the ventral edge of the jaw, is visible. This identification is also supported by the undulating alveolar margin of the jaw (Bardack 1965) and the slight sigmoidal curve of the symphysis; both the alveolar margin and symphysis are relatively straight in the other two genera.

Two North American species of Xiphactinus are currently considered valid (see discussion below). The teeth of $X$. audax lack carinae, while those of $X$. vetus are somewhat laterally compressed and recurved, and bear an anterior or anterolingual carina and sometimes a posterior carina (Schwimmer et al., 1997). The teeth of the Alberta specimen closely resemble those of $X$. audax, and therefore, this specimen can be confidently assigned to this species. The relative size of the Albertan fish can be estimated based on the size of the jaw fragment. Bardack (1965) noted that the mean length of the symphysis in $X$. audax is $8.7 \mathrm{~cm}$, with a range of 6.0-13.85 based on measurements of 81 specimens. The symphysis of the Alberta specimen was about
$9.2 \mathrm{~cm}$, indicating the fish that this dentary came from was of an intermediate size, possibly around $3 \mathrm{~m}$ in total length.

Additional Material: A second specimen (Fig. 3), in the collections of the Canadian Museum of Nature (specimen number CMN 51273), likely came from the same area as TMP 1973.011.3081. The label states it is from Bad Heart, Alberta, collected in 1961 by Robert Cochrane, and identified as cf. Xiphactinus by 'CMS' (which would be C.M. Sternberg). CMN 51273 preserves the symphysis and partial left and right dentaries, along with other elements that could benefit from more preparation. The heterodont, thecodont dentition, sigmoidal curve of the symphysis and the undulating dorsal edge of the dentary confirm the identification of Xiphactinus. The teeth have no carinae and circular cross section (pers. obs.), and so we consider this specimen to also belong to $X$. audax. The CMN specimen is from a slightly smaller fish than the TMP specimen.

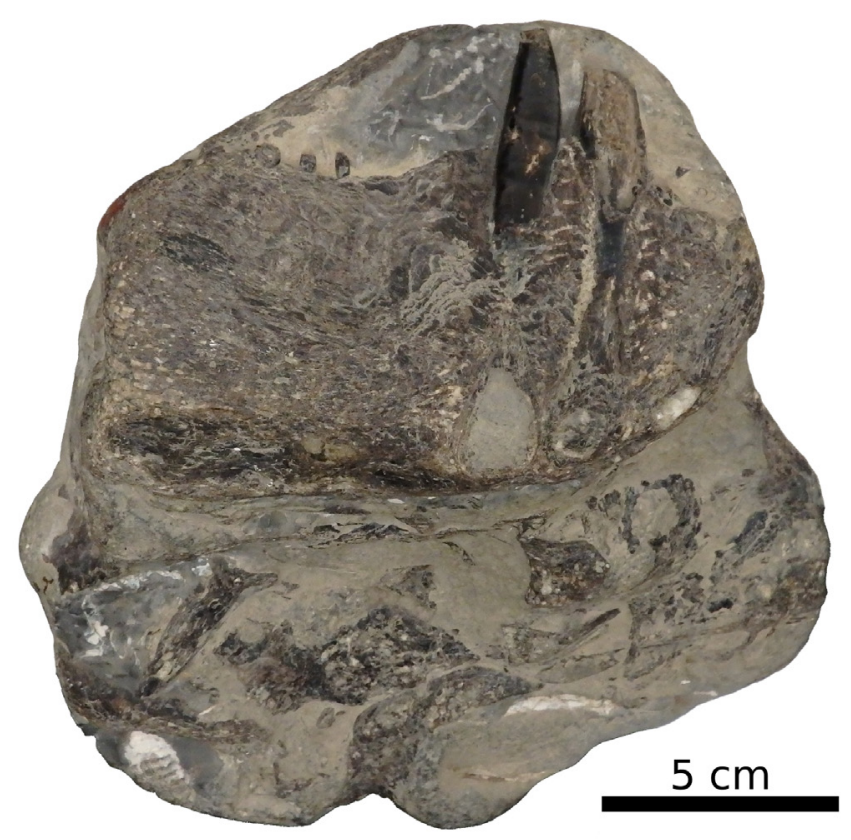

Figure 3. CMN 51273, partial jaws of Xiphactinus audax Leidy 1870 , in right lateral view.

\section{DISCUSSION}

The most comprehensive review of Xiphactinus was by Bardack (1965), as part of a larger treatise on the taxonomy of chirocentrid fishes. The understanding of the relationship of chirocentrids and ichthyodectids has changed considerably since that publication [see Nelson (1973) and Patterson and Rosen (1977) for a more thorough review of Ichthyodectiformes taxonomy]; however, Bardack's revisions to the generic taxonomy of Xiphactinus have largely stood unchanged. Bardack (1965) retained four species in the genus Xiphactinus, but did so based on their distribution in time and space rather than for morphological 
reasons. Xiphactinus gaultinus and Xiphactinus mantelli are known from Europe, while Xiphactinus australis is from Australia. Specimens of these three species are quite fragmentary (Bardack 1965) making them difficult to distinguish from $X$. audax. All the North American species known at that time were considered synonyms of $X$. audax by Bardack (1965). New records of Xiphactinus sp. have since been recovered from South America (Carrillo-Briceño et al. 2012), and a separate species of Xiphactinus from North America, $X$. vetus, was re-erected by Schwimmer et al. (1997). This second species of North American Xiphactinus can be relatively easily distinguished from $X$. audax by the morphology of the teeth (see Remarks above). The two North American species show a large amount of overlap in their distributions (Fig. 4; Tab. 1). Xiphactinus audax has been found from northern Alberta through the Western Interior Basin and along the Atlantic Coastal plain. Remains of $X$. vetus are most commonly found along the Atlantic Coastal plain (Schwimmer et al. 1997), although recent finds in Wyoming have significantly extended its range (DeMar and Breithaupt 2006). The relative rarity of $X$. vetus in the Western Interior or $X$. audax along the eastern seaboard may have more to do with the lack of appropriate aged marine deposits, rather than any

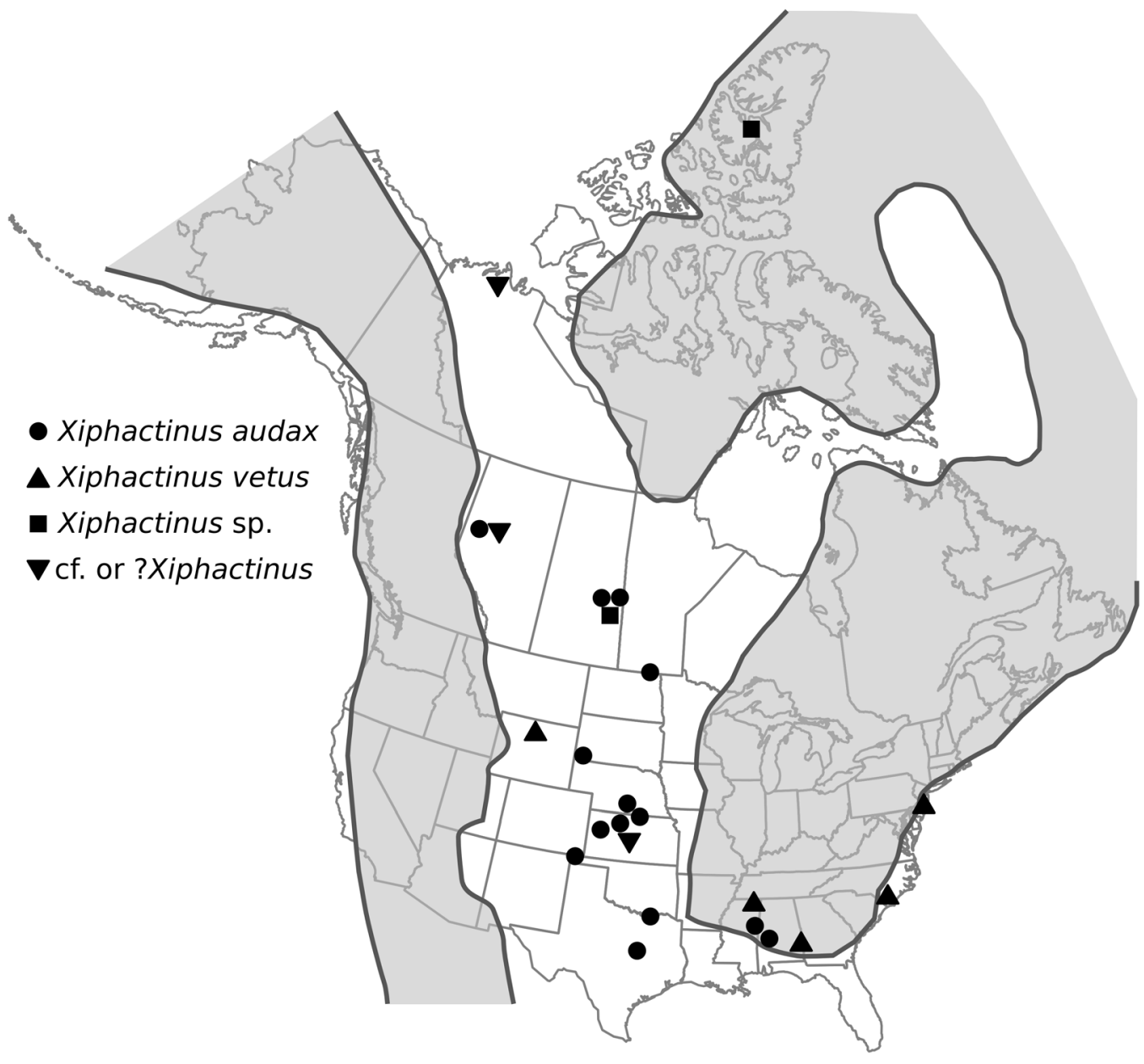

true range boundary (Schwimmer et al. 1997). Although the two species are found within geographically overlapping strata, they do not appear to have co-existed. Definitive remains of $X$. audax have been recovered from Cenomanian through to early Campanian deposits, with a possible occurrence from the upper Albian of Kansas (Williston 1894 ), while $X$. vetus is only known from younger, middle Campanian through to lower Maastrichtian deposits (Schwimmer et al. 1997; DeMar and Breithaupt 2006). Although presently far south of the Arctic Circle, the locality where TMP 1973.011.3081 was found would have been close to $65^{\circ} \mathrm{N}$ during the early Campanian (Irving et al. 1993; Smith et al. 1994; Bell et al. 2014; Vavrek et al. 2014a).

Excluding the two records of indeterminate Xiphactinus and Xiphactinus-like taxa from Arctic Canada, this represents the northernmost record of $X$. audax. During an expedition in 1965 to the early Campanian (Hills et al. 1999) Smoking Hills Formation along the Anderson River, Northwest Territories, Russell (1967) found and uncovered the tail and posterior abdominal portion of a very large fish he referred to as ?Xiphactinus. However, due to a number of factors the specimen was not collected, and so its identity cannot be confirmed. A second specimen of a possible Xiphactinus from the Arctic was reported by Hills et al. (1999), from the Kanguk

Figure 4. Map of confirmed or possible Xiphactinus occurrences from Canada and the United States. Grey shading indicates non-marine regions. Coastline shown is approximately that of the early Turonian, adapted from Kauffman (1984). In cases where multiple localities are in very close proximity, some localities have been omitted for clarity. For a more comprehensive list of localities, please consult the supplementary materials, as well as Bardack (1965) and Schwimmer et al. (1997). 












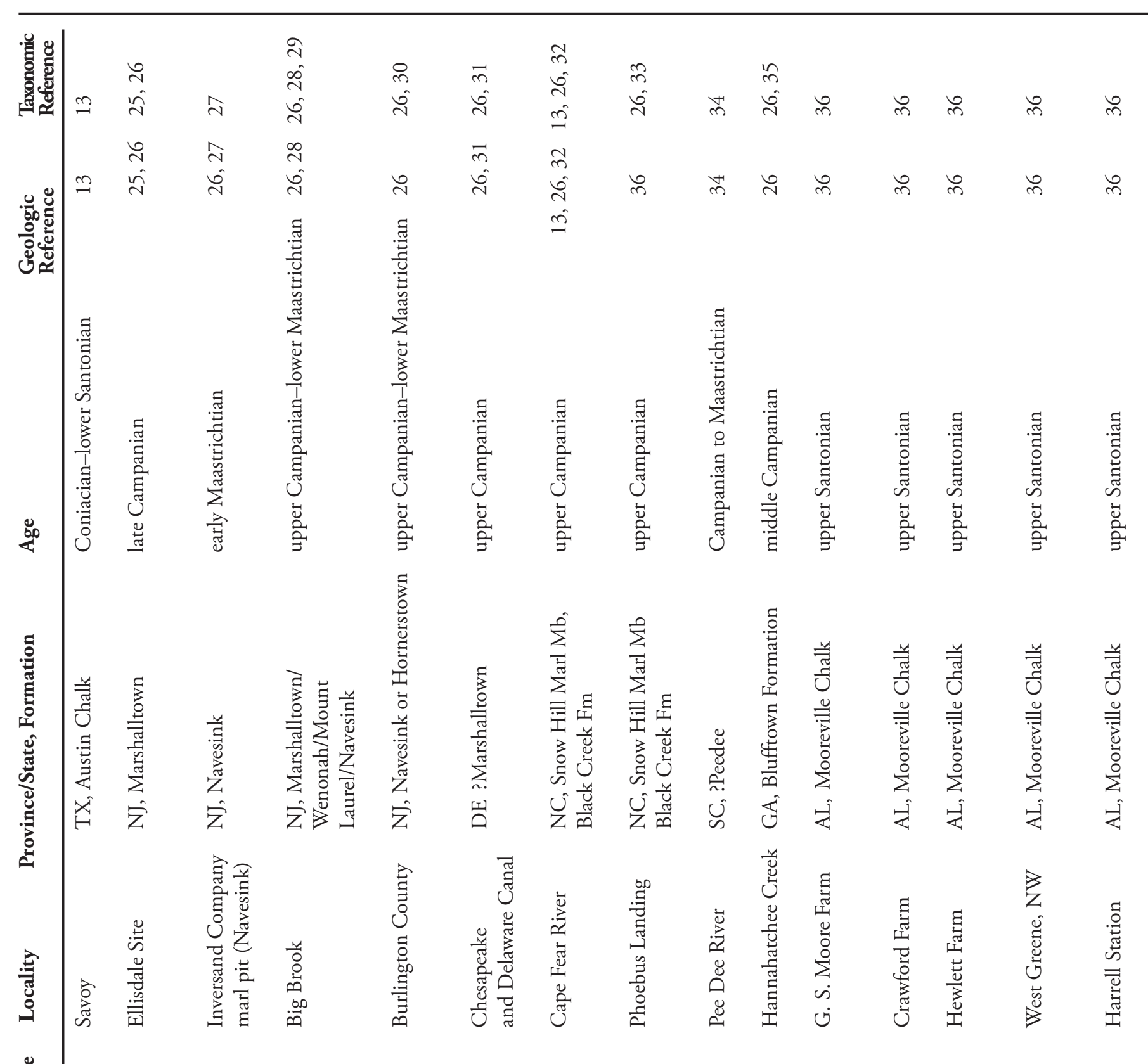

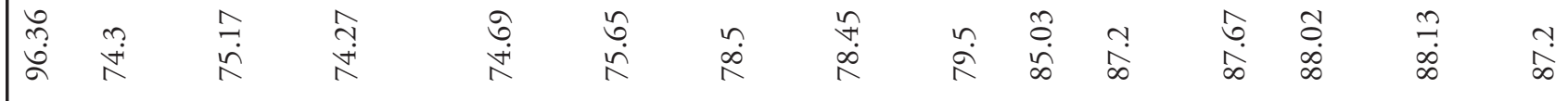

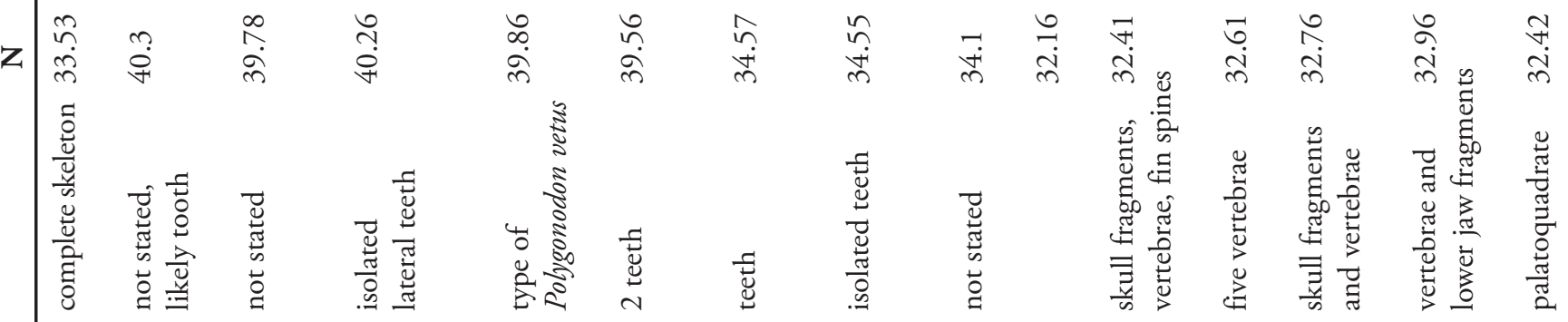

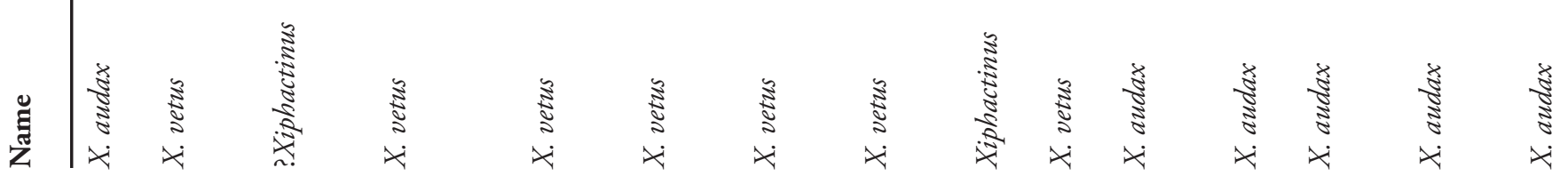




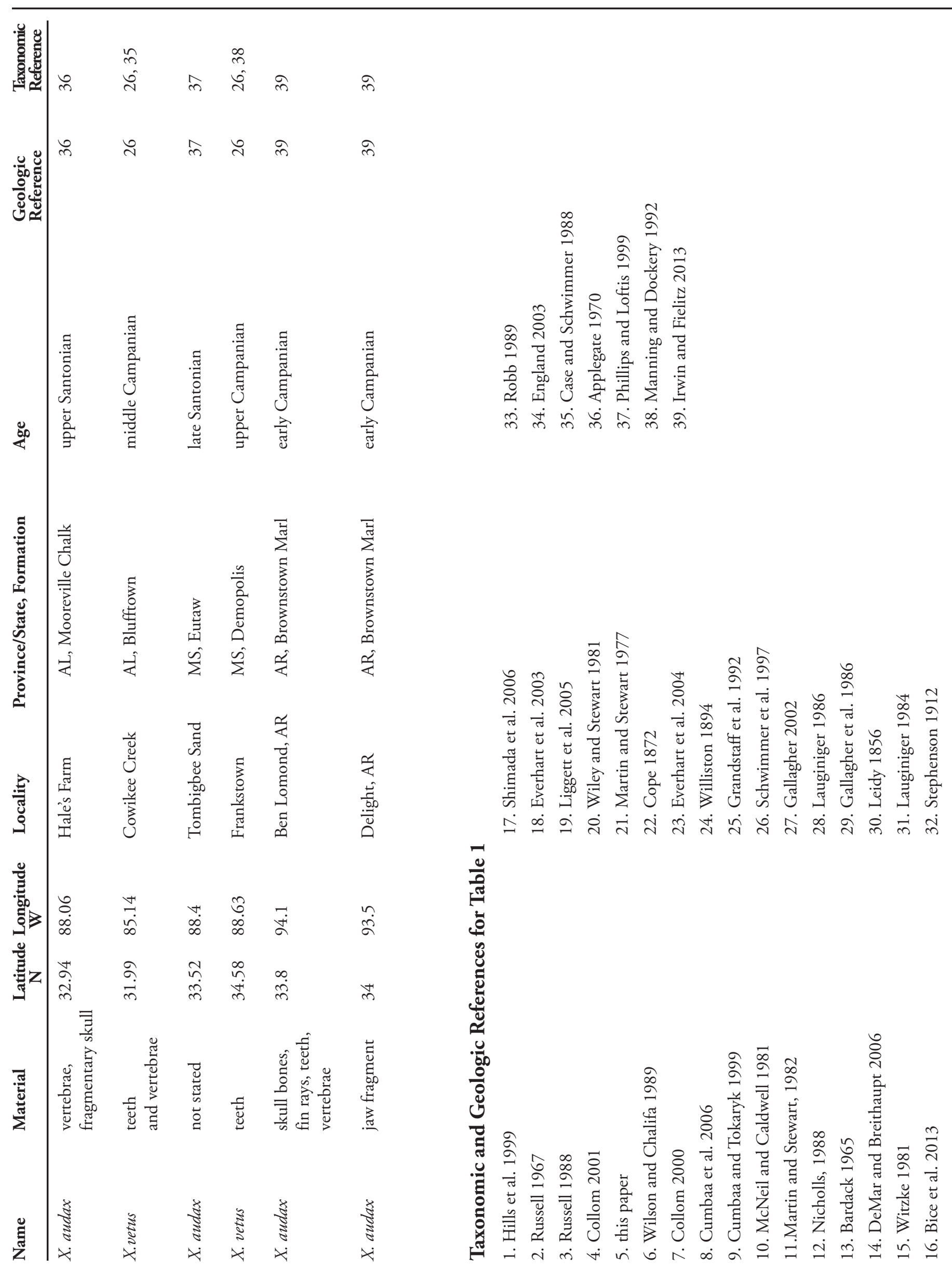


Formation on Ellesmere Island. The specimen was collected but not described, and at this time cannot be relocated, so it is presently unknown even what element(s) is/are represented. This locality was dated as early to middle Campanian based on palynomorphs recovered from the same section. Additional material (in the CMN collections) identified by S.L. Cumbaa as belonging to cf. Xiphactinus and Xiphactinus audax was collected from Cretaceous deposits of Devon Island by the field parties of J. Eberle and K. Chin in 1998 and 2003. The geographic location of some of these finds is interesting, as during the Late Cretaceous, these Arctic localities may have actually been closer to Europe than many of the locations within the Western Interior Basin (e.g., see map in Vavrek et al. 2014a). Regardless of the exact taxonomic affiliation of these Arctic finds, Xiphactinus audax still possesses an incredibly large geographic range, stretching for thousands of kilometres within the Western Interior Basin. Although this additional record of Xiphactinus audax adds to our growing knowledge of marine vertebrates from the northern part of the Western Interior Basin (e.g., Cumbaa and Tokaryk 2009; Cumbaa et al. 2006; Cook et al. 2008, 2010, 2012; Bell et al. 2014; Vavrek et al. 2014b) the region still remains understudied compared to more southerly regions (Cook et al. 2008, Vavrek et al. 2014b). Further work in northern areas is required so as to better understand the true ranges and biogeography of marine vertebrates during the Late Cretaceous.

\section{ACKNOWLEDGEMENTS}

We thank Margaret Currie (CMN) and Kevin Seymour (ROM) for searching through their respective collections to find elusive material. Brandon Strilisky (RTMP) facilitated the loan of TMP 1973.011.3081. The South Peace Regional Archives was very helpful in providing access to George Robinson's collections ledger to allow re-identification of the original site TMP 1973.011.3081 was found. Our thanks to the editor and reviewers for suggesting improvements to the manuscript.

\section{LITERATURE CITED}

Applegate, S.P. 1970. The vertebrate fauna of the Selma Formation of Alabama. Part VIII. The fishes. Fieldiana: Geology Memoirs 3:365-433.

Bardack, D. 1965. Anatomy and evolution of chirocentrid fishes. University of Kansas Paleontological Contributions 10:1-88.

Bardack, D., and G. Sprinkle. 1969. Morphology and relationships of saurocephalid fishes. Fieldiana Geology 16:297-340.

Bell, P.R., F. Fanti, M.T. Mitchell, and P.J. Currie. 2014. Marine reptiles (Plesiosauria and Mosasauridae) from the Puskwaskau Formation (Santonian-Campanian), West-Central Alberta. Journal of Paleontology 88:187-194.
Bice, K.N., K. Shimada, and J.I. Kirkland. 2013. Late Cretaceous marine fishes from the upper Greenhorn Limestone in southeastern Nebraska. Transactions of the Kansas Academy of Science 116:22-26.

Carrillo-Briceño, J., J. Alvarado-Ortega, and C. Torres. 2012. Primer registro de Xiphactinus Leidy, 1870 (Teleostei, Ichthyodectiformes) en el Cretácico Superior de América del Sur (Formación La Luna, Venezuela). Revista Brasileira de Paleontologia 15:327-335.

Case, G.R., and D.R. Schwimmer. 1988. Late Cretaceous fish from the Blufftown Formation (Campanian) in Western Georgia. Journal of Paleontology 62:290-301.

Collom, C.J. 2000. High-resolution stratigraphy, regional correlation, and report of molluscan faunas: Colorado Group (Cenomanian-Coniacian interval, Late Cretaceous), east-central Saskatchewan. Saskatchewan Geological Survey, Summary of Investigations 1:82-97.

Collom, C.J. 2001. Systematic paleontology, biostratigraphy, and paleoenvironmental analysis of the Upper Cretaceous Wapiabi Formation and equivalents; Alberta and British Columbia, Western Canada. Ph.D. thesis, University of Calgary, Calgary, Alberta, 835 pp.

Cook, T.D., M.V.H. Wilson, and A.M. Murray. 2008. A middle Cenomanian euselachian assemblage from the Dunvegan Formation of northwestern Alberta. Canadian Journal of Earth Sciences 45:1185-1197.

Cook, T.D., M.V.H. Wilson, and M.G. Newbrey. 2010. The first record of the large Cretaceous lamniform shark, Cardabiodon ricki, from North America and a new empirical test for its presumed antitropical distribution. Journal of Vertebrate Paleontology, 30:643-649.

Cook, T.D., M.V.H. Wilson, A.M. Murray, A.G. Plint, M.G. Newbrey, and M.J. Everhart. 2012. A high latitude euselachian assemblage from the early Turonian of Alberta, Canada. Journal of Systematic Palaeontology 11:1-33.

Cope, E.D. 1872. Sketch of an expedition in the valley of the Smoky Hill River in Kansas. Proceedings of the American Philosophical Society 12:174-176.

Cumbaa, S.L., and T.T. Tokaryk. 1999. Recent discoveries of Cretaceous marine vertebrates on the eastern margins of the Western Interior Seaway. Saskatchewan Geological Survey, Summary of Investigations 1:94-99.

Cumbaa, S.L., C. Schroder-Adams, R.G. Day, and A.J. Phillips. 2006. Cenomanian bonebed faunas from the northeastern margin, western interior seaway, Canada. Late Cenomanian vertebrates from the Western Interior. Bulletin of New Mexico Museum of Natural History and Science 35:139-155.

DeMar Jr., D.G., and B.H. Breithaupt. 2006. The nonmammalian vertebrate microfossil assemblages of the Mesaverde Formation (Upper Cretaceous, Campanian) of the Wind River and Bighorn Basins, Wyoming. Bulletin of the New Mexico Museum of Natural History and Science 35:33-53.

England, B. 2003. Late Cretaceous marine vertebrates from the Pee Dee River valley, Florence County, South Carolina. Journal of Vertebrate Paleontology 23(supplement 3):48A. 
Everhart, M.J., P.A. Everhart, E. Manning, and D. Hattin. 2003. A middle Turonian marine fish fauna from the Blue Hill Shale Member, Carlile Shale, of north central Kansas. Journal of Vertebrate Paleontology 23(supplement 3):49A.

Everhart, M.J., P.A. Everhart, and K. Ewell. 2004. A marine ichthyofauna from the upper Dakota Sandstone (Late Cretaceous). Abstracts of oral presentations and posters, Joint Annual Meeting of the Kansas and Missouri Academies of Science, p. 48.

Gallagher, W.B. 2002. Faunal changes across the CretaceousTertiary (K-T) boundary in the Atlantic coastal plain of New Jersey: restructuring the marine community after the K-T mass-extinction event. Catastrophic events and mass extinctions: impacts and beyond. Geological Society of America Special Paper 356:291-301.

Gallagher, W.B., D.C. Parris, and E.E. Spamer. 1986. Paleontology, biostratigraphy, and depositional environments of the Cretaceous-Tertiary transition in the New Jersey coastal plain. The Mosasaur 3:1-35.

Gardiner, B. 1966. Catalogue of Canadian fossil fishes. Royal Ontario Museum Life Science Contribution 68:1-154.

Grandstaff, B.S., D.C. Parris, R.K. Denton Jr., and W.B. Gallagher. 1992. Alphadon (Marsupialia) and Multituberculata (Allotheria) in the Cretaceous of Eastern North America. Journal of Vertebrate Paleontology 12:217-222.

Hills, L. V., E.L. Nicholls, L.K. Núńez-Betelu, and D.J. McIntyre. 1999. Hesperornis (Aves) from Ellesmere Island and palynological correlation of known Canadian localities. Canadian Journal of Earth Sciences 36:1583-1588.

Hu, Y.G., and Plint, A.G. 2009. An allostratigraphic correlation of a mudstone-dominated, syn-tectonic wedge: The Puskwaskau Formation (Santonian-Campanian) in outcrop and subsurface, Western Canada Foreland Basin. Bulletin of Canadian Petroleum Geology, 57:1-33..

Irving, E., P.J. Wynne, and B.R. Globerman. 1993. Cretaceous paleolatitudes and overprints of North American craton. Geological Association of Canada, Special Paper 39:91-96.

Irwin, K.J., and C. Fielitz. 2013. Ichthyodectiform fishes from the Late Cretaceous (Campanian) of Arkansas, USA; pp. 247266 in G. Arratia, H.-P. Schultze, and M.V.H. Wilson (eds). Mesozoic Fishes 5 - Global Diversity and Evolution. Verlag Dr. Friedrich Pfeil, München, Germany.

Kauffman, E.G. 1977. Geological and biological overview: Western Interior Cretaceous Basin. The Mountain Geologist 14:75-99.

Kauffman, E.G. 1984. Paleobiogeography and evolutionary response dynamic in the Cretaceous Western Interior Seaway of North America. Geological Association of Canada, Special Paper 27:273-306

Lauginiger, E.M. 1984. An upper Campanian vertebrate fauna from the Chesapeake and Delaware Canal, Delaware. The Mosasaur 2:141-149

Lauginiger, E.M. 1986. An Upper Cretaceous vertebrate assemblage from Big Brook, New Jersey. The Mosasaur 3:53-61.
Leidy, J. 1856. Notices of remains of extinct vertebrated animals of New Jersey, collected by Prof. Cook of the State Geological Survey under the direction of Dr. W. Kitchell. Proceedings of the Academy of Natural Sciences of Philadelphia 8:220-221.

Leidy, J. 1870. Remarks on ichthyodorulites and on certain fossil Mammalia. Proceedings of the Academy of Natural Sciences of Philadelphia 22:12-13.

Liggett, G.A., K. Shimada, S.C. Bennett, and B.A. Schumacher. 2005. Cenomanian (Late Cretaceous) reptiles from northwestern Russell County, Kansas. Paleobios, 25:9-17.

Manning, E.M., and D.T. Dockery III. 1992. A guide to the Frankstown vertebrate fossil locality (Upper Cretaceous), Prentiss County, Mississippi. Mississippi Department of Environmental Quality, Office of Geology Circular 4:1-43.

Martin, L.D., and J.D. Stewart. 1977. The oldest (Turonian) mosasaurs from Kansas. Journal of Paleontology 51:973-975.

Martin, L.D., and J.D. Stewart. 1982. An ichthyornithiform bird from the Campanian of Canada. Canadian Journal of Earth Sciences 19:324-327.

Nelson, G.J. 1973. Notes on the structure and relationships of certain Cretaceous and Eocene fishes. American Museum of Natural History Novitates 2524:1-31.

Nicholls, E.L. 1988. Marine vertebrates of the Pembina Member of the Pierre Shale (Campanian, Upper Cretaceous) of Manitoba and their significance to the biogeography of the Western Interior Seaway. Ph.D. Thesis, University of Calgary, Calgary, Alberta, 317 pp.

Patterson, C., and D.E. Rosen. 1977. Review of ichthyodectiform and other Mesozoic teleost fishes and the theory and practice of classifying fossils. Bulletin of the American Museum of Natural History 158:81-172.

Phillips, G., and E. Loftis. 1999. A significant late Santonian (Upper Cretaceous) vertebrate fossil site in Lowndes Co., Mississippi. Journal of the Mississippi Academy of Sciences 44:42.

Robb, A.J., III. 1989. The Upper Cretaceous (Campanian, Black Creek Formation) fossil fish fauna of Phoebus Landing, Bladen County, North Carolina. The Mosasaur 4:75-92.

Russell, D.A. 1967. Cretaceous vertebrates from the Anderson River, N.W.T. Canadian Journal of Earth Sciences 4:21-38.

Russell, D.A. 1988. A checklist of North American marine Cretaceous vertebrates including fresh water fishes. Tyrrell Museum of Palaeontology Occasional Papers 4:1-58.

Schwimmer, D.R., J.D. Stewart, and G.D. Williams. 1997. Xiphactinus vetus and the distribution of Xiphactinus species in the eastern United States. Journal of Vertebrate Paleontology 17:610-615.

Shimada, K., and M.J. Everhart. 2004. Shark-bitten Xiphactinus audax (Teleostei: Ichthyodectiformes) from the Niobrara Chalk (Upper Cretaceous) of Kansas. The Mosasaur 7:35-39.

Shimada, K., B.A. Schumacher, J.A. Parkin, and J.M. Palermo. 2006. Fossil marine vertebrates from the lowermost Greenhorn Limestone (Upper Cretaceous: middle Cenomanian) in southeastern Colorado. Journal of Paleontology 80:1-45. 
Smith, A.G., D.G. Smith, and B.M. Funnell. 1994. Atlas of Cenozoic and Mesozoic coastlines. Cambridge University Press, Cambridge, 99 pp.

Stephenson, L.W. 1912. The Cretaceous formations of the coastal plains of North Carolina. North Carolina Geological Survey Report 3:73-171.

Stott, D.F. 1963. The Cretaceous Alberta Group and equivalent rocks, Rocky Mountain Foothills, Alberta. Geological Survey of Canada, Memoir 317, 306 pp.

Stott, D.F. 1967. The Cretaceous Smoky Group, Rocky Mountain Foothills, Alberta and British Columbia. Geological Survey of Canada, Bulletin 132, 133 pp.

Vavrek, M.J., L.V. Hills, and P.J. Currie. 2014a. A hadrosaurid (Dinosauria: Ornithischia) from the Late Cretaceous (Campanian) Kanguk Formation of Axel Heiberg Island, Nunavut, Canada, and its ecological and geographical implications. ARCTIC 67:1-9.

Vavrek, M.J., A.M. Murray, and P.R. Bell. 2014b. An early Late Cretaceous (Cenomanian) sturgeon (Acipenseriformes) from the Dunvegan Formation, northwestern Alberta, Canada. Canadian Journal of Earth Sciences 51:677-681.

Wiley, E.O., and J.D. Stewart. 1981. Urenchelys abditus, new species, the first undoubted eel (Teleostei: Anguilliformes) from the Cretaceous of North America. Journal of Vertebrate Paleontology 1:43-47.

Williston, S.W. 1894. On various vertebrate remains from the lowermost Cretaceous of Kansas. Kansas University Quarterly 3(1):1-4, pl. I.

Wilson, M.V.H., and Y. Chalifa. 1989. Fossil marine actinopterygian fishes from the Kaskapau Formation (Upper Cretaceous: Turonian) near Watino, Alberta. Canadian Journal of Earth Sciences 26:2604-2620.

Witzke, B.J. 1981. Cretaceous vertebrate fossils of Iowa and nearby areas of Nebraska, South Dakota and Minnesota; pp. 105-122 in R.L. Brenner, R.F. Bretz, B.J. Bunker, D.L. Iles, G.A. Ludvigson, R.M. McKay, D.L. Whitley, and B.J. Witzke (eds). Cretaceous Stratigraphy and Sedimentation in Northwest Iowa, Northeast Nebraska, and Southeast South Dakota. Iowa Geological Survey Guidebook Series, Number 4. 